\title{
Antepartum hemorrhage and its fetomaternal outcome: a retrospective study
}

\author{
Saloni K. Gandhi, Ayushi P. Vamja*, Kishor P. Chauhan
}

Department of Obstetrics and Gynecology, Sumandeep Vidyapeeth Deemed to be University, Vadodara, Gujarat, India

Received: 26 August 2020

Revised: 01 October 2020

Accepted: 02 October 2020

\section{*Correspondence:}

Dr. Ayushi P. Vamja,

E-mail: ayushivamja@gmail.com

Copyright: (c) the author(s), publisher and licensee Medip Academy. This is an open-access article distributed under the terms of the Creative Commons Attribution Non-Commercial License, which permits unrestricted non-commercial use, distribution, and reproduction in any medium, provided the original work is properly cited.

\section{ABSTRACT}

Background: Antepartum hemorrhage (APH) is defined as any bleeding from or into the genital tract after the period of viability and before the delivery of the baby. Aim of the research was to study the fetomaternal outcome in patients with APH.

Methods: The present study was a retrospective observational study undertaken in Obstetrics and Gynaecology department of Dhiraj General Hospital, during a period of 1.5 years from November 2018 to May 2020 in 84 cases of antepartum hemorrhage. Only patients with APH $>28$ weeks gestational age and willing to participate in study were included. Open STAT statistical software has been used to analyse the data in this study.

Results: The incidence of antepartum hemorrhage was $2.86 \%$. Maximum patients of APH lie between the age group of 26-34 years. In abruptio placenta (AP) $65 \%$ and in placenta previa (PP) $77.2 \%$ of the patients were multiparous. APH presents mostly between 34-36 weeks. Around 90\% patients of APH required blood transfusion. APH overall shows increased rate of cesarean sections upto $62 \%$. Around $9.5 \%$ patients went into shock, $4.7 \%$ had disseminated intravascular coagulation (DIC), 3.5\% postpartum hemorrhage (PPH) and $8.3 \%$ had wound gap and peurperial pyrexia. $23.8 \%$ babies had asphyxia of which $60 \%$ were contributed to PP and $40 \%$ were in AP group. Respiratory distress syndrome was in $7.1 \%$ babies of which both groups equally contributed. Septicemia was seen in $13 \%$ and jaundice in $29.8 \%$.

Conclusions: Higher rates of neonatal intensive care unit (NICU) admission and stay were seen with these complications. This study showed $20.2 \%$ perinatal deaths as outcome of APH and $14.2 \%$ still births.

Keywords: Antepartum hemorrhage, Fetomaternal outcome, Placenta previa, Abruptio placenta

\section{INTRODUCTION}

Antepartum haemorrhage (APH) is defined as bleeding from or into the genital tract after 28 weeks of gestation and before delivery of the baby. It is an obstetric emergency which may lead to maternal and perinatal morbidity and mortality. APH complicates about $2-5 \%$ of all the pregnancies. ${ }^{1}$

APH is mainly due to placenta praevia (PP) and abruption placentae (AP). Other causes include vasa praevia, succenturiate placenta, and placental infections.
PP refers to the condition when the placenta is partially or completely implanted over the lower uterine segment, either over or near the internal os.

AP is the condition where bleeding occurs due to partial or complete premature separation of a normally situated placenta before delivery.

Other causes of APH not related to pregnancy are cervical polyp, carcinoma cervix, varicose veins, local trauma, and cervical erosion. APH is associated with multifetal 
gestation, malpresentation, preterm labor, pre-eclampsia, eclampsia, hydramnios and chorioamnionitis.

Maternal complications due to APH are: postpartum hemorrhage (PPH), shock, sepsis and disseminated intravascular coagulation (DIC).

Fetal complications associated with APH are: preterm birth, low birth weight, intrauterine death, congenital malformation and birth asphyxia. ${ }^{2}$

In developing countries illiteracy, unawareness of facilities available, widespread preexisting anemia, restricted transport facilities, and restricted medical facilities are largely responsible for high maternal mortality rate (MMR).

Perinatal mortality is less than 10 per 1000 total births in developed countries while it is much higher in India 60/1000 total births. ${ }^{3}$

A significant reduction in APH associated maternal and perinatal morbidity and mortality can be done with aggressive management.

Decreased perinatal and maternal morbidity and mortality is observed with good antenatal care, use of ultrasonography for placental localization and early and timely diagnosis of abruptio placenta, good transport facility, better obstetrical and anesthetic facilities, improved blood bank facilities and advanced neonatal care facilities.

This study was done to evaluate the fetomaternal outcome of antepartum hemorrhage.

\section{METHODS}

The present study is a retrospective observational study undertaken during a period of 1.5 years from November 2018 to May 2020 in Dhiraj General Hospital, Vadodara.

Patients of APH who fulfilled the inclusion and exclusion criteria were included as cases in the study. Total 84 cases were taken which included PP in 44 patients and AP in 40 patients.

Open STAT statistical software has been used to analyze the data in this study.

\section{Inclusion criteria}

Singleton pregnancy.

APH with gestational age between 28-42 weeks.

\section{Exclusion criteria}

Multiple pregnancy.
Local cause of bleeding per vaginum.

All cases of bleeding per vagina with gestational age $<28$ weeks.

Patient suffering from any other bleeding disorder.

On admission, a complete history was taken including past history regarding antenatal care taken, previous spotting per vaginum and associated pre eclampsia. Her gestational age was calculated using her last menstrual period and using first scan.

General physical examination was done to assess both maternal and fetal condition. Gentle abdominal examination was done. The duration and amount of bleeding, its association with pain was noted. Amount of blood loss outside hospital was estimated by asking the patient and attender and examining the patient. Visible blood loss was noted based on pads soaked.

Blood investigations included hemoglobin and hematocrit estimation, complete blood count and for grouping and cross matching, bleeding time, and clotting time on urgent basis.

The initial management included: intravenous fluids and blood products depending on the patients general condition. Ultrasonography (USG) was done to establish cause and severity of APH and fetal condition estimation.

The subsequent management was divided into expectant management and definitive management based on gestational age, fetal and maternal status and extent of haemmorrhage.

The fetomaternal outcome in APH was then analyzed.

\section{Statistical analysis}

Open STAT statistical software has been used to analyze the data in this study.

\section{RESULTS}

The present study was carried out on 84 patients who presented with APH in emergency, over a period of 1.5 years from November 2019 to April 2020.

Table 1: Distribution according to maternal age.

\begin{tabular}{|llll|}
\hline $\begin{array}{l}\text { Maternal } \\
\text { age } \\
\text { (years) }\end{array}$ & $\begin{array}{l}\text { Placenta } \\
\text { previa } \\
(\mathbf{n = 4 4})(\%)\end{array}$ & $\begin{array}{l}\text { Abruption } \\
(\mathbf{n = 4 0}) \\
(\%)\end{array}$ & $\begin{array}{l}\text { Total cases } \\
(\mathbf{n}=\mathbf{8 4})(\%)\end{array}$ \\
\hline $\mathbf{1 8}$ & $1(2.3)$ & $1(2.5)$ & $2(2.4)$ \\
\hline $\mathbf{1 8 - 2 5}$ & $14(31.7)$ & $10(25)$ & $24(28.5)$ \\
\hline $\mathbf{2 6 - 3 4}$ & $25(56.9)$ & $27(67.5)$ & $52(62)$ \\
\hline $\mathbf{2 3 5}$ & $4(9.1)$ & $2(5)$ & $6(7.1)$ \\
\hline
\end{tabular}


Maximum patients of APH lie between the age group of 26-34 years in both PP 25(56\%) and in AP 27(67.5\%).

In AP $65 \%$ and in $\mathrm{PP} 77.2 \%$ of the patients were multiparous.

Table 2: Distribution according to the parity.

\begin{tabular}{|llll|}
\hline Parity & $\begin{array}{l}\text { Placenta } \\
\text { previa } \\
(\mathbf{n = 4 4 )}\end{array}$ & $\begin{array}{l}\text { Abruptio } \\
\text { placenta } \\
(\mathbf{n = 4 0 )}\end{array}$ & $\begin{array}{l}\text { Total } \\
(\mathbf{n}=\mathbf{8 4})\end{array}$ \\
\hline Primigravida & $10(22.8)$ & $14(35)$ & $24(28.5)$ \\
\hline $\mathbf{2}^{\text {nd }}$ to $\mathbf{4}^{\text {th }}$ & $32(72.6)$ & $23(57.5)$ & $55(65.5)$ \\
\hline $\mathbf{2 5}^{\text {th }}$ & $2(4.6)$ & $3(7.5)$ & $5(6)$ \\
\hline
\end{tabular}

Majority of cases of PP present between 34-36 weeks while that of AP present in $37-39$ weeks. Overall APH presents mostly between $34-36$ weeks.

Table 3: Distribution according to gestational age.

\begin{tabular}{|llll|}
\hline $\begin{array}{l}\text { Gestational } \\
\text { age (weeks) }\end{array}$ & $\begin{array}{l}\text { Placenta } \\
\text { previa } \\
(\mathbf{n = 4 4 )}\end{array}$ & $\begin{array}{l}\text { Abruptio } \\
\text { placenta } \\
(\mathbf{n = 4 0 )}\end{array}$ & $\begin{array}{l}\text { Total } \\
(\mathbf{n = 8 4})\end{array}$ \\
\hline $\mathbf{2 8 - 3 2}$ & $8(18.2)$ & $4(10)$ & $12(14.3)$ \\
\hline $\mathbf{3 1 - 3 3}$ & $14(31.2)$ & $6(15)$ & $20(23.7)$ \\
\hline $\mathbf{3 4 - 3 6}$ & $15(34.6)$ & $6(15)$ & $21(25)$ \\
\hline $\mathbf{3 7 - 3 9}$ & $3(6.8)$ & $14(35)$ & $17(20.2)$ \\
\hline $\mathbf{3 3 9}$ & $4(9.2)$ & $10(25)$ & $14(16.8)$ \\
\hline
\end{tabular}

$88 \%$ of the patients were anaemic with a majority of $50 \%$ having hemoglobin levels between 8.1-10 gm\%.

Table 4: Distribution according to hemoglobin estimation of the patients.

\begin{tabular}{|llll|}
\hline $\begin{array}{l}\text { Haemoglobin } \\
(\text { gm \%) }\end{array}$ & $\begin{array}{l}\text { Placenta } \\
\text { previa }\end{array}$ & $\begin{array}{l}\text { Abruptio } \\
\text { placenta }\end{array}$ & $\begin{array}{l}\text { Total } \\
(\%)\end{array}$ \\
\hline$<6$ & 4 & 2 & $6(7.1)$ \\
\hline $\mathbf{6 . 1 - 8}$ & 12 & 14 & $26(30.9)$ \\
\hline $\mathbf{8 . 1 - 1 0}$ & 22 & 20 & $42(50)$ \\
\hline$>\mathbf{1 0 . 1}$ & 6 & 4 & $10(12)$ \\
\hline
\end{tabular}

With $88 \%$ patients being anemic at the time of admission around $90 \%$ patients of APH required blood transfusion.

Table 5: APH and blood transfusion.

\begin{tabular}{|llll|}
\hline $\begin{array}{l}\text { No. of blood } \\
\text { transfusion } \\
\text { required }\end{array}$ & $\begin{array}{l}\text { Placenta } \\
\text { previa } \\
(\mathbf{n = 4 4 )}\end{array}$ & $\begin{array}{l}\text { Abruptio } \\
\text { placenta } \\
(\mathbf{n = 4 0 )}\end{array}$ & $\begin{array}{l}\text { Total } \\
(\mathbf{n}=\mathbf{8 4})\end{array}$ \\
\hline $\mathbf{0}$ & $6(13.6)$ & $3(7.5)$ & $9(10.7)$ \\
\hline $\mathbf{1}$ & $16(36.4)$ & $10(25)$ & $26(30.9)$ \\
\hline $\mathbf{2}$ & $15(34.1)$ & $18(45)$ & $33(39.4)$ \\
\hline $\mathbf{3}$ & $4(9.1)$ & $4(10)$ & $8(9.5)$ \\
\hline $\mathbf{4}$ & $2(4.5)$ & $3(7.5)$ & $5(5.9)$ \\
\hline$>\mathbf{5}$ & $1(2.2)$ & $2(5)$ & $3(3.5)$ \\
\hline
\end{tabular}

$90 \%$ of cases of PP underwent cesarean while $30 \%$ cases of AP underwent cesarean.

$10 \%$ delivered vaginally in PP while $70 \%$ delivered vaginally in AP.

However, APH overall shows increased rate of cesarean sections upto $62 \%$.

Vaginal delivery rate was only upto $38 \%$.

Table 6: Mode of delivery in APH.

\begin{tabular}{|llll|}
\hline Mode of delivery & $\begin{array}{l}\text { Placenta } \\
\text { previa } \\
(\mathbf{n = 4 4 )}\end{array}$ & $\begin{array}{l}\text { Abruptio } \\
\text { placenta } \\
(\mathbf{n}=\mathbf{4 0})\end{array}$ & $\begin{array}{l}\text { Total } \\
(\mathbf{n}=\mathbf{8 4})\end{array}$ \\
\hline LSCS & $40(90)$ & $12(30)$ & $52(62)$ \\
\hline Vaginal & $4(10)$ & $28(70)$ & $32(38)$ \\
\hline
\end{tabular}

Above table shows that around $9.5 \%$ patients went into shock, $4.7 \%$ had DIC, 3.5\% PPH and $8.3 \%$ had wound gap and peurperial pyrexia each contributing to maternal morbidity. In our study, there was no maternal mortality seen.

Table 7: Maternal morbidity in APH.

\begin{tabular}{|llll|}
\hline Type & $\begin{array}{l}\text { Placenta } \\
\text { previa }\end{array}$ & $\begin{array}{l}\text { Abruptio } \\
\text { placenta }\end{array}$ & Total \\
\hline $\begin{array}{l}\text { Peurperial } \\
\text { pyrexia }\end{array}$ & 3 & 4 & $7(8.3)$ \\
\hline Shock & 4 & 4 & $8(9.5)$ \\
\hline DIC & 0 & 4 & $4(4.7)$ \\
\hline PPH & 2 & 1 & $3(3.5)$ \\
\hline Wound gap & 2 & 5 & $7(8.3)$ \\
\hline
\end{tabular}

Table 8 shows that $23.8 \%$ babies had asphyxia of which $60 \%$ were contributed to PP and $40 \%$ were in AP group. Respiratory distress syndrome was in $7.1 \%$ babies of which both groups equally contributed. Septicemia was seen in $13 \%$ and jaundice in $29.8 \%$.

Higher rates of NICU admission and stay were seen with these complications.

Table 8: Neonatal morbidity in APH.

\begin{tabular}{|llll|}
\hline Type & $\begin{array}{l}\text { Placenta } \\
\text { previa }\end{array}$ & $\begin{array}{l}\text { Abruptio } \\
\text { placenta }\end{array}$ & Total \\
\hline Asphyxia & 12 & 8 & $20(23.8)$ \\
\hline Septicemia & 8 & 3 & $11(13.1)$ \\
\hline Jaundice & 15 & 10 & $25(29.8)$ \\
\hline $\begin{array}{l}\text { Respiratory } \\
\text { distress } \\
\text { syndrome }\end{array}$ & 3 & 3 & $6(7.1)$ \\
\hline $\begin{array}{l}\text { Congenital } \\
\text { malformation }\end{array}$ & 0 & 0 & 0 \\
\hline Hypoglycemia & 0 & 1 & $1(1.2)$ \\
\hline
\end{tabular}


This study showed $20.2 \%$ perinatal deaths as outcome of APH and $14.2 \%$ still births.

Table 9: Perinatal mortality in APH.

\begin{tabular}{|llll|}
\hline Type & $\begin{array}{l}\text { Placenta } \\
\text { previa } \\
(\mathbf{n = 4 4 )}(\%)\end{array}$ & $\begin{array}{l}\text { Abruptio } \\
\text { placenta } \\
(\mathbf{n}=40)(\%)\end{array}$ & $\begin{array}{l}\text { Total } \\
(\mathbf{n = 8 4}) \\
(\%)\end{array}$ \\
\hline Live birth & $42(95.5)$ & $30(75)$ & $72(85)$ \\
\hline Still birth & $2(4.5)$ & $10(25)$ & $12(14.2)$ \\
\hline $\begin{array}{l}\text { Early } \\
\text { neonatal } \\
\text { death }\end{array}$ & $2(4.5)$ & $4(10)$ & $6(7.14)$ \\
\hline $\begin{array}{l}\text { Perinatal } \\
\text { death }\end{array}$ & $10(25)$ & $7(23.3)$ & $17(20.2)$ \\
\hline
\end{tabular}

\section{DISCUSSION}

An obstetrician has to tackle life threatening conditions like APH often and take timely and judicious decisions of terminating pregnancy keeping in mind the welfare of the mother, fetus or both.

In the present study highest number of cases $(62 \%)$ were in the age group of 26-34 years in both PP $25(56 \%)$ and in AP $27(67.5 \%)$ with a mean age of 28 years. This was comparable to a study conducted by Bako et al. ${ }^{4}$ Were $45 \%$ of cases were in the age group of 21-29 years with a mean of 27 years. Another study conducted by Mourya et al. ${ }^{5}$ Showed maximum cases in the age group of 21-29 years with a mean of 23 years.

The incidence of APH was more common in multiparous (71.5\%) than nulliparous (28.5\%). In AP 65\% and in PP $77.2 \%$ of the patients were multiparous.

This is comparable to Adekanle et al study. With $75.2 \%$ multipara and $24.8 \%$ nullipara. ${ }^{6}$ In a study by Cotton et al $83.2 \%$ of patients with APH were multiparous and $16.8 \%$ nulliparous. $^{7}$

Majority of cases of PP present between 34-36 weeks while that of AP present in 37-39 weeks. Overall APH presents mostly between 34-36 weeks. In the present study majority deliveries were conducted before 36 weeks gestation $63 \%$ with a mean gestational age of 34.4 weeks which is comparable to a study by Bhandiwad et al in which $52.5 \%$ were in $28-32$ weeks group. ${ }^{8}$ In contrast to the present study done by Maurya et al $63 \%$ of patients had gestational age $\geq 37$ weeks. ${ }^{5}$ Bako et al also observed that $64 \%$ of the patients had gestational age $\geq 37$ weeks. ${ }^{4}$

In the present study $88 \%$ of the patients were anaemic with a majority of 50\% having hemoglobin levels between 8.1$10 \mathrm{gm} \%$.

Similar findings were observed by Chakarborty et al who reported that $60 \%$ of their patients were anemic. ${ }^{9}$ In contrast Sarwar et al reported higher incidence (96.2\%) and Bhandiwad et al reported lower incidence of $35 \% .{ }^{10}$

With $88 \%$ patients being anemic at the time of admission around $90 \%$ patients of APH required blood transfusion. In a study conducted by Crenshaw et al only $24 \%$ of patients with $\mathrm{PP}$ required blood transfusion in comparison to $90 \%$ in present study. ${ }^{11}$

Maximum no of patients 33 (39.4\%) in this study required 2 units of blood transfusion (BT). This was similar to the study done by William et al in which $19 \%$ required two units in each group. ${ }^{12}$ In this study, $2(5 \%)$ patients of abruption and 1 patient (2.2\%) with PP had >5 BT.

In the present study, $70 \%$ patients with abruption delivered vaginally while $30 \%$ were delivered by lower segment caesarean section (LSCS). This study was compared to the study by Hibbard and Jeffcoate in which vaginal delivery was reported in $62.2 \%$ and Bako et al reported $63.3 \%$ of normal deliveries in patients with abruption. ${ }^{4,13}$ Also in a study done by Vaidya et al $73 \%$ cases delivered vaginally. ${ }^{14}$

90\% PP were delivered by LSCS and 10\% vaginally which was comparable to the study by Bako et al in which $13.2 \%$ delivered vaginally. ${ }^{4}$

In this study $9.5 \%$ patients went into shock, $4.7 \%$ had DIC, $3.5 \% \mathrm{PPH}$ and $8.3 \%$ had wound gap and peurperial pyrexia each.

This was comparable to the study done by Chakraborty et al which showed $16.2 \%$ incidence of PPH and Hurd et al reported $13.3 \%$. Significant shock was present in $10 \%$ of cases. ${ }^{9}$

$23.8 \%$ babies had asphyxia of which $60 \%$ were contributed to PP and $40 \%$ were in AP group. Respiratory distress syndrome was in $7.1 \%$ babies of which both groups equally contributed. Septicemia was seen in $13 \%$ and jaundice in $29.8 \%$. Higher rates of NICU admission and stay were seen with these complications.

In contrast to this only $7.58 \%$ in study by Jaju et al had jaundice. Prematurity was observed in $82.8 \%$ in this study contrary to which $25.76 \%$ in Jaju et al had prematurity. ${ }^{15}$

This study showed $20.2 \%$ perinatal deaths as outcome of $\mathrm{APH}$ and $14.2 \%$ still births.

\section{CONCLUSION}

This study concludes that APH is still a leading cause of maternal morbidity and mortality in our country. Causes of APH are placental abruption and PP. The commonest mode of delivery was cesarean section. Maternal morbidity was higher in the abruption group in terms of shock, DIC and renal failure and fetal morbidity and mortality was also high as compared to PP group. This was 
because most of the cases in abruption group presented late and already complicated at the time of admission, while PP was diagnosed early using ultrasound before they became symptomatic clinically, therefore, managed early. Though maternal mortality has reduced with effective management of antepartum hemorrhage, perinatal mortality was high because of prematurity. Hence, timely cesarean section, blood transfusion, correction of anemia and wider acceptance of expectant line of management in properly selected patients have helped to further lower the maternal morbidity and mortality.

\section{ACKNOWLEDGMENTS}

Authors wish to record their deep sense of gratitude and profound thanks to guide and research supervisor Dr. Kishor Chauhan, Professor and HOD, SBKS MIRC, Dhiraj Hospital, Vadodara, for his keen interest, inspiring guidance, constant encouragement, with the work during all stages, to bring this article into fruition.

Funding: No funding sources

Conflict of interest: None declared

Ethical approval: The study was approved by the Institutional Ethics Committee

\section{REFERENCES}

1. Ananth CV, Smulian JC, Vintzileos AM. Incidence of placental abruption in relation to cigarette smoking and hypertensive disorders during pregnancy: A metaanalysis of observational studies. Obstet Gynecol. 1999;93:622-8.

2. Cunningham F, Leveno K, Bloom S, Hauth J, Gilstrap L, Rouse D, et al. Obstetrical haemorrhage. Williams Obstetrics. 23rd Edition, New York, McGraw Hill Professionals. 2009.

3. Park K. Maternal and child health. In: Park's textbook of preventive and social medicine. 17th edition. Banarasi Das Bhanot 'Jabalpur. 2000.
4. Bako B, Audu BM, Chama CM, Kyari O, Idrissa A. A 8 year clinical review of antepartum hemorrhage 1999-2006. BOMJ. 2008;5(2):14-21.

5. Maurya A, Arya S. Study of antepartum hemorrhage and its maternal and fetal outcome. Int J Sci Res Pub. 2014;4(2):1-8.

6. Adekanle D, Adeyemi A, Fadero F. Ante-partum hemorrhage and pregnancy outcome in Lautech Teaching Hospital, southwestern Nigeria. J Med Medical Sci. 2011;2(12):1243-7.

7. Cotton DB, Read JA, Paul RH, Quilligan EJ. The conservative aggressive management of placenta previa. Am J Obstet Gynecol. 1980;164:687-95.

8. Bhandiwad A, Bhandiwad AA. A study of maternal and fetal outcome in Antepartum haemorrhage. J Evid Based Med Healthc. 2014;1(6):406-27.

9. Chakraborty B, De KC. Evaluation of third trimester bleeding with reference to maternal and perinatal outcome. J Obstet Gynecol India. 1993;42:166-71.

10. Sarwar I, Abbasi AN, Islam A. Abruptio placenta and its complication at Ayub teaching hospital Abbottabad. J Ayub Med Coll Abbottabad. 2006;12731.

11. Crenshaw C, Jones DE, Parker RT. Placenta previa: a survey of twenty years experience with improved perinatal survival by expectant therapy and cesarean delivery. Obstet Gvnecol Surv. 1973;28(7):461-70.

12. William MA, Mittendorf R. Increasing maternal age, a determinant for placenta previa. More important than increasing parity PJ Reprod Med. 1993;38:4258.

13. Dutta DC. Antepartum hemorrhage. In: Hiralal Konar, editor. Textbook of obstetrics. 6th edition. New Central Book Agency, Calcutta. 2004;243-61.

Cite this article as: Gandhi SK, Vamja AP, Chauhan KP. Antepartum hemorrhage and its fetomaternal outcome: a retrospective study. Int $\mathbf{J}$ Reprod Contracept Obstet Gynecol 2020;9:4562-6. 